\title{
VIRGIN COCONUT OIL MEMPERCEPAT PENYEMBUHAN LUKA PERINEUM DI PUSKESMAS RAWAT INAP KOTA DENPASAR
}

\author{
Ni Nyoman Sumiasih, Ni Ketut Somoyani, Ni Wayan Armini \\ Jurusan Kebidanan Politeknik Kesehatan Denpasar \\ sumiasih.ninyoman@gmail.com
}

\begin{abstract}
One means to speed up the perineal tear healing is by the application of virgin coconut oil (VCO) that have efficacy to accelerate wound healing. This study aims to find differences in healing of the perineum tear treated to the normal delivery care added with VCO. This research was conducted in Puskesmas Denpasar from June to early to October 2015. The type of research is experimental design with post test only control, with a time series approach. The study population was postpartum mothers who gave birth in Puskesmas Denpasar who suffered level II lacerations. The sample of the control group are 16 people who were treated to the standard normal delivery, and the treatment group are 16 people who were treated with the addition of Virgin Coconut Oil (VCO).

Average time of tear recovery in the control group took 6 to 8 days whilst in the treatment group it took 4 to 5 days. The differences of healing in the control and treatment groups were analyzed using the Mann-Whitney statistical test, with results showing that healing treatment groups is faster than the control groups. Therefore it could be concluded that perineal tear healing treated to the standard normal delivery care added with VCO is faster than those treated only to the standard normal delivery care.

It is suggested to all health care practitioners who serve women with perineal laceration to give treatment to the standard normal delivery care added with VCO to speed up healing.
\end{abstract}

Keywords: perineal tear, standard normal delivery care, virgin coconut oil.

ABSTRAK. Untuk mempercepat penyembuhan luka perineum ini,virgin coconut oil (VCO) memiliki khasiat mempercepat penyembuhan luka. Penelitian ini bertujuan untuk menemukan perbedaan penyembuhan luka perineum yang dirawat sesuai asuhan persalinan normal (APN) dengan ditambah VCO. Penelitian ini dilakukan di Puskesmas Rawat Inap Kota Denpasar dari bulan Juni sampai awal Oktober 2015. Jenis penelitian adalah eksperimental design post test only control group dengan pendekatan time series. Populasi penelitian ini ibu nifas melahirkan di Puskesmas Rawat Inap Kota Denpasar yang mengalami laserasi tingkat II, dengan sampel 16 orang kelompok kontrol dirawat sesuai APN, dan 16 orang kelompok perlakuan dirawat sesuai APN ditambah $V C O$.

Rata-rata penyembuhan luka pada kelompok kontrol 6 sampai 8 hari sedangkan pada kelompok perlakuan 4 sampai 5 hari. Perbedaan penyembuhan kelompok kontrol dan perlakuan dianalisis dengan uji statistic Mann Whitney Test, hasilnya penyembuhan kelompok perlakuan lebih cepat daripada kelompok kontrol. Dapat disimpulkan penyembuhan luka perineum yang dirawat sesuai standar APN ditambah VCO lebih cepat dibandingkan dengan yang dirawat sesuai standar APN saja. Disarankan kepada semua praktisi kesehatan yang melayani perempuan dengan laserasi perineum merawat sesuai APN ditambahkan dengan $V C O$ untuk mempercepat penyembuhan.

Kata Kunci: luka perineum, Standar Asuhan Persalinan Normal, VCO 


\section{Pendahuluan}

Masa nifas adalah masa sejak seorang perempuan melahirkan sampai 42 hari setelah melahirkan. Masa ini merupakan masa yang sangat komplek yang dialami oleh seorang perempuan terutama yang baru pertamakali melahirkan. Pengalaman seorang ibu nifas tersebut antara lain, merasakan menjadi seorang ibu, mengembalikan kondisi seperti pada masa sebelum hamil (penyembuhan luka-luka jalan lahir, postur tubuh, organ-organ reproduksi), mulai belajar menyusui, merawat anak, dan banyak lagi peran-peran baru yang harus dipelejari oleh seorang ibu baru.

Luka jalan lahir yang dialami oleh ibu nifas memerlukan kecermatan dan sangat membutuhkan perhatian untuk mencegah terjadinya infeksi. Perlukaan jalan lahir sangat berbeda dengan luka-luka di bagian tubuh lain karena terletak di bagian yang sulit dilihat oleh ibu itu sendiri, dan terletak di daerah yang rawan terkena infeksi karena berkaitan dengan eliminasi yaitu berdekatan dengan pengeluaran kencing dan faeses. Di samping itu juga karena terletak di daerah yang sangat sensitif di antara kedua lipatan pantat yang kita pergunakan duduk maka sangat nyeri apabila kita pakai duduk. Maka dari itu perawatan perlukaan jalan lahir perlu mendapat perhatian khusus dari tenaga kesehatan, khususnya bidan yang memiliki wewenang langsung di bidang asuhan organ reproduksi untuk memberi rasa nyaman dan mencegah komplikasi yang mungkin bisa terjadi seperti infeksi pada jahitan perineum. ${ }^{1}$

Secara umum frekuensi infeksi pada masa nifas adalah sekitar 1-3\%. Secara proporsional angka infeksi menurut jenis infeksi adalah infeksi jalan lahir 25-55\%, infeksi saluran kencing 30-60\%, infeksi pada payudara $5-10 \%$ dan infeksi campuran $2-5 \%$ dari seluruh kasus infeksi. ${ }^{2}$ Kejadian infeksi puerperalis ini sering terjadi setelah pasien pulang dari rumah sakit khususnya setelah 24 jam post partum. Faktor predisposisi dari infeksi puerperalis ini antara lain, partus di rumah yang kurang bersih, sosial ekonomi yang rendah, kurang gizi, anemia, primipara, luka jalan lahir, partus lama, terlalu sering dilakukan pemeriksaan dalam (vaginal toucher), seksio sesaria, partus tindakan, perdarahan post partum. Sumber lain 
lagi bisa berasal dari kuman-kuman yang ada dalam saluran vagina wanita itu sendiri. Oleh karena itu perlu melakukan pencegahan infeksi, bekerja dengan cara aseptik dan memberikan antibiotika untuk mencegah infeksi puerperalis.

Infeksi jalan lahir sangat rentan terjadi pada ibu nifas yang mengalami luka perineum yang tidak terawat dengan baik dan bisa menimbulkan rasa sangat nyeri, sulit duduk, dan bahkan bisa mengganggu peran ibu untuk menyusui bayinya yang sedang sangat membutuhkan nutrisi yang terbaik dari ibu. Untuk mencegah infeksi pada luka jalan lahir virgin coconut oil (VCO) yang memiliki khasiat sebagai antiseptik, antiinfeksi dan dapat mengurangi rasa nyeri serta memberi kenyamanan.

Pada penelitian eksperimental sungguhan yang dilakukan oleh Jaya, Fidi Bhawana, (2015) mengenai Efek Virgin Coconut Oil dalam Mempercepat Penyembuhan Luka., pada 30 ekor mencit galur Swiss Webster jantan dengan luka insisi yang dibagi secara acak dalam 3 kelompok perlakuan $(\mathrm{n}=10)$ yaitu kelompok VCO, kelompok kontrol positif Povidone Iodine $10 \%$ dan kelompok kontrol negative $\mathrm{NaCl}$ 0,9\%. Hasil Penelitian didapatkan kecepatan penyembuhan luka yang paling cepat adalah pada kelompok VCO. Simpulan VCO mempercepat penyembuhan luka secara -makroskopis dan potensinya setara dengan Povidone Iodine 10\% secara mikroskopis. ${ }^{3}$

Pada penelitian tentang pemanfaatan virgin coconut oil, dengan teknik massage diharapkan dapat meminimalisir terjadinya infeksi dan dapat menjadi terapi penyembuhan luka dekubitus derajat II. Penelitian ini bertujuan untuk mengetahui pengaruh pemberian massage dengan $V C O$ dalam penyembuhan luka dekubitus derajat II. Desain penelitian Case Study dengan menggunakan metode analisis jalinan. Teknik pengambilan sampel yaitu purposive sampling dengan jumlah respondendua orang lansia yang tinggal di Panti Wredha yang berbeda. $^{4}$

Peneliti menganalisis mengenai: tindakan massage, respon pasien lansia terhadap tindakan massage, perkembangan luka dekubitus dan kendala yang ditemui saat penelitian. Terapi massage dengan metode effleurage berpengaruh positif yaitu 
memberikan sensasi nyaman terhadap kedua pasien lansia.Hasil penelitian terapi massage dengan $\mathrm{VCO}$ memberikan perkembangan luka yang cukup signifikan, dengan hasil luka tampak kering, warna kecoklatan, eritema tampak samar dan jaringan luka menutup tanpa adanya tandatanda infeksi. Terapi massage dengan $V C O$ efek dalam meminimalisir terjadinya infeksi dan dapat menurunkan derajat luka dekubitus. ${ }^{4}$

Minyak kelapa murni (virgin coconut oil) adalah minyak kelapa yang dibuat dari bahan baku kelapa segar, diproses dengan tanpa pemanasan sama sekali dan tanpa bahan kimia. Minyak kelapa murni dengan kandungan utama asam laurat ini memiliki sifat antibiotik, anti bakteri,jamur, dan anti virus.Tubuh mengolah asam laurat menjadi monolaurin yang bertanggung jawab sebagai penghancur virus, dan bakteri, seperti bakteri Streptococcus, Staphylococcus Aureus yang sangat berbahaya, dan jamur Candida Albicans yang sangat umum membuat infeksi pada manusia. ${ }^{5}$

Berdasarkan penelitian yang dilakukan oleh Mary Enig (2013), hampir $50 \%$ dari fatty acid dalam kelapa adalah lauric acid. Lauric acid adalah perubahan dari fatty acid, yang mana tubuh manusia atau hewan yang meningkatkan fungsinya menjadi monolaurin. Monolaurin merupakan anti-viral, antibacterial, and antiprotozoal monoglyceride yang mana dalam tubuh manusiaatau hewan berguna untuk menghancurkan lipid coated viruses seperti HIV, herpes, cytomegalovirus, influenza, various pathogenic bacteria dan tidak memiliki efek samping. ${ }^{6}$ Berdasarkan uraian di atas peneliti tertarik untuk meneliti perbedaan lama penyembuhan luka jahitan perineum ibu nifas antara yang dirawat sesuai standar asuhan persalinan normal dengan ditambah virgin coconut oil di Puskesmas Rawat Inap Denpasar.

Masalah yang sering kita temui pada masa nifas awal adalah kurang nyamannya ibu nifas menyusui bayinya karena diganggu oleh adanya jahitan bagi ibu yang mengalami laserasi perineum. Dampak dari ketidaknyamanan tersebut adalah terjadi kegagalan dalam memberikan ASI ekslusif pada bayinya. Dengan alasan itu peneliti ingin meneliti, "Apakah virgin 
coconut oil mempercepat penyembuhan luka jahitan perineum pada ibu nifas di Puskesmas Rawat Inap Kota Denpasar". Penelitian ini bertujuan untuk menemukan perbedaan lama penyembuhan luka perineum yang dirawat sesuai standar asuhan normal dengan ditambah virgin coconut oil.

\section{Metodelogi}

Penelitian ini adalah penelitian eksperimental design rancangan post test only control group dengan pendekatan time series, pengukuran efektivitas perlakuan didapat dari membandingkan lama waktu penyembuhan luka perineum pada kelompok eksperimen dan kelompok kontrol. Pada kelompok eksperimen jahitan luka perineum dirawat dengan menggunakan virgin coconut oil, sedangkan pada kelompok kontrol perawatan sesuai APN (dicuci dengan sabun 3-4 kali sehari).

Penelitian ini dilaksanakan di Puskesmas rawat inap Kota Denpasar, Puskesmas IV Denpasar Selatan dan Puskesmas Pembantu Dauh Puri (wilayah kerja Puskesmas II Denpasar Barat), dari bulan Juni sampai dengan Oktober 2015.

Populasi dalam penelitian ini adalah seluruh ibu nifas di yang melahirkan di Puskesmas IV Denpasar Selatan dan Puskesmas Pembantu Dauh Puri dengan kriteria inklusi dalam penelitian ini adalah ibu setelah melahirkan berdomisili di Kota Denpasar dan mengalami laserasi tingkat dua, yang melakukan penjahitan luka adalah bidan dengan pendidikan minimal D III Kebidanan dengan pengalaman minimal dua tahun dengan memakai benang jahit cat gut/cromik no. 2.0. Sedangkan kriteria eksklusi adalah pendidikan di bawah SMP, menderita penyakit kronik yang bisa menghambat proses penyembuhan .luka seperti anemia atau DM, mengalami komplikasi selama persalinan dan masa nifas, riwayat mengalami robekan perineum sebelumnya.

Sampel penelitian ini adalah seluruh ibu nifas yang memenuhi kriteria inklusi dan eksklusi. Menutrut Roscoe dalam Sugiono, 2008 jumlah sampel untuk penelitian eksperimen sederhana yang menggunakan kelompok eksperimen dan kelompok kontrol, maka, jumlah anggota sampel masing-masing kelompok 10-20 orang. ${ }^{7}$ Pengambilan sampel dari masing-masing kelompok antara 10- 
20 tergantung banyaknya persalinan pada saat penelitian dengan cara non probability sampling yaitu consecutive sampling

Data yang dikumpulkan data primer, yaitu penyembuhan luka dilakukan observasi langsung pada responden dengan pedoman REEDA Scale Data dianalisis dengan uji statistik non-parametrik yaitu Mann-

Whitney, dengan bantuan komputer

\section{Hasil dan Pembahasan}

Sampai akhir waktu penelitian responden yang dapat diamati adalah 16 responden kelompok kontrol, dan 16 orang kelompok perlakuan yang diberikan $V C O$. Hasil pengamatan disajikan pada tabel berikut.

Tabel 1.

Distribusi Karakteristik Responden Penelitian

\begin{tabular}{|c|c|c|c|c|}
\hline \multirow[b]{2}{*}{ Karakteristik } & \multicolumn{4}{|c|}{ Kelompok } \\
\hline & $\begin{array}{c}\text { Kontrol } \\
(n=16)\end{array}$ & $\%$ & $\begin{array}{c}\text { Intervensi } \\
(\mathbf{n}=16)\end{array}$ & $\%$ \\
\hline \multicolumn{5}{|l|}{ Umur } \\
\hline 20-35 tahun & 14 & 87,5 & 16 & 100 \\
\hline$>35$ tahun & 2 & 12,5 & 0 & 0 \\
\hline \multicolumn{5}{|l|}{ Pendidikan } \\
\hline Sekolah Menengah Pertama & 3 & 18,75 & 4 & 25,00 \\
\hline Sekolah Menengah Atas & 13 & 81,25 & 11 & 68,75 \\
\hline Perguruan Tinggi & 0 & 0 & 1 & 6,25 \\
\hline \multicolumn{5}{|l|}{ Jumlah anak } \\
\hline 1 orang & 11 & 68,75 & 10 & 62,5 \\
\hline $2-3$ orang & 5 & 31,25 & 6 & 37,5 \\
\hline
\end{tabular}

Dari tabel 1. tampak bahwa umur terbanyak pada kelompok kontrol dan intervensi adalah 23-35 tahun $(87,5 \%, 100 \%)$, pendidikan menengah atas $(81,25 \%, 68,75 \%)$, jumlah anak 1 orang $(68,75 \%$, $62,5 \%$,).
Penyembuhan luka dinilai dari perubahan tanda REEDA yang tercermin dari perubahan skor. 
Tabel 2.

REEDA Scale

\begin{tabular}{|c|c|c|c|c|}
\hline \multirow{2}{*}{$\begin{array}{l}\text { Tanda } \\
\text { REEDA }\end{array}$} & \multicolumn{4}{|c|}{ Skor } \\
\hline & 0 & 1 & 2 & 3 \\
\hline $\begin{array}{l}\text { Redness } \\
\text { (kemerahan) }\end{array}$ & $\begin{array}{l}\text { Tidak } \\
\text { ada }\end{array}$ & $\begin{array}{l}0,25 \mathrm{~cm} \text { di luar } \\
\text { kedua sisi luka }\end{array}$ & $\begin{array}{l}\text { Antara } 0,25-0,5 \mathrm{~cm} \\
\text { di luar kedua sisi } \\
\text { luka }\end{array}$ & $\begin{array}{l}\text { Lebih dari } 0,5 \mathrm{~cm} \text { di } \\
\text { luar kedua sisi luka }\end{array}$ \\
\hline $\begin{array}{l}\text { Echymosis } \\
\text { (perdarahan } \\
\text { bawah kulit) }\end{array}$ & $\begin{array}{l}\text { Tidak } \\
\text { ada }\end{array}$ & $\begin{array}{l}\text { Mencapai } \\
0,25 \mathrm{~cm} \text { di kedua } \\
\text { sisi luka atau } 0,5 \\
\mathrm{~cm} \text { di salah satu } \\
\text { sisi luka }\end{array}$ & $\begin{array}{l}0,25-1 \mathrm{~cm} \text { di kedua } \\
\text { sisi luka atau } 0,5-2 \\
\mathrm{~cm} \text { di salah satu } \\
\text { sisi luka }\end{array}$ & $\begin{array}{l}>1 \mathrm{~cm} \text { di kedua sisi } \\
\text { luka atau }>2 \mathrm{~cm} \mathrm{di} \\
\text { salah satu sisi luka }\end{array}$ \\
\hline $\begin{array}{l}\text { Edema } \\
\text { (bengkak) }\end{array}$ & $\begin{array}{l}\text { Tidak } \\
\text { ada }\end{array}$ & $\begin{array}{l}<1 \mathrm{~cm} \text { dari luka } \\
\text { insisi }\end{array}$ & $1-2 \mathrm{~cm}$ dari luka & $\begin{array}{l}>2 \mathrm{~cm} \text { dari luka } \\
\text { insisi }\end{array}$ \\
\hline $\begin{array}{l}\text { Dicharge } \\
\text { (perubahan } \\
\text { lokhea) }\end{array}$ & $\begin{array}{l}\text { Tidak } \\
\text { ada }\end{array}$ & Serum & Serosanguineous & Berdarah, purulent \\
\hline $\begin{array}{l}\text { Approximatio } \\
n \\
\text { (pertautan } \\
\text { jaringan) }\end{array}$ & Tertutup & $\begin{array}{l}\text { Kulit tampak } \\
\text { terbuka }<3 \mathrm{~cm}\end{array}$ & $\begin{array}{l}\text { Kulit dan lemak } \\
\text { subkutan tampak } \\
\text { terpisah }\end{array}$ & $\begin{array}{l}\text { Kulit subkutan dan } \\
\text { fascia tampak } \\
\text { terpisah kulit dan } \\
\text { lemak }\end{array}$ \\
\hline
\end{tabular}

Hasil pengamatan terhadap responden

pada kelompok perlakuan maupun kelompok kontrol disajikan pada Tabel 3 berikut. 
Tabel 3

Luka Berdasarkan Skor (REEDA) Laserasi Perineum Derajat II Persalinan Spontan dengan Perawatan Luka Sesuai Standard APN dengan Ditambah VCO

\begin{tabular}{|c|c|c|c|c|}
\hline \multirow{2}{*}{$\begin{array}{c}\text { Hari } \\
\mathrm{Ke}-\end{array}$} & \multirow{2}{*}{$\begin{array}{l}\text { Penjumlahan } \\
\text { Skor } \\
\text { REEDA }\end{array}$} & \multicolumn{2}{|c|}{ Kelompok } & \multirow[t]{2}{*}{ Nilai $p$} \\
\hline & & $\begin{array}{c}\text { Kontrol } \\
\mathrm{n}=16(100 \%)\end{array}$ & $\begin{array}{c}\text { Intervensi } \\
\mathrm{n}=16(100 \%)\end{array}$ & \\
\hline & 2 & $2(12,50 \%)$ & $7(43,75 \%)$ & \multirow{3}{*}{0,008} \\
\hline & 3 & $5(31,25 \%)$ & $7(43,75 \%)$ & \\
\hline & 4 & $9(56,25 \%)$ & $2(12,5 \%)$ & \\
\hline & 0 & 0 & $1(6,25 \%)$ & \multirow{5}{*}{0,03} \\
\hline & 1 & 0 & $3(18,75 \%)$ & \\
\hline & 2 & $4(25 \%)$ & $5(31,25 \%)$ & \\
\hline & 3 & $11(68,75 \%)$ & $7(43,75 \%)$ & \\
\hline & 4 & $1(6,25 \%)$ & 0 & \\
\hline & 0 & 0 & $2(12,5 \%)$ & \multirow{4}{*}{0,00} \\
\hline & 1 & 0 & $8(50 \%)$ & \\
\hline & 2 & $14(87,5 \%)$ & $6(37,5 \%)$ & \\
\hline & 3 & $2(12,5 \%)$ & 0 & \\
\hline & 0 & 0 & $5(31,25 \%)$ & \multirow{5}{*}{0,00} \\
\hline & 1 & $6(37,5 \%)$ & $11(68,75 \%)$ & \\
\hline & 2 & $6(37,5 \%)$ & 0 & \\
\hline & 3 & $3(18,75 \%)$ & 0 & \\
\hline & 4 & $1(6,25 \%)$ & 0 & \\
\hline & 0 & 0 & $16(80 \%)$ & \multirow{4}{*}{0,00} \\
\hline & 1 & $12(75 \%)$ & $0(20 \%)$ & \\
\hline & 2 & $3(18,75 \%)$ & 0 & \\
\hline & 3 & $1(6,25 \%)$ & 0 & \\
\hline & 0 & $4(25 \%)$ & $16(100 \%)$ & \multirow[t]{3}{*}{0,00} \\
\hline & 1 & $8(50 \%)$ & 0 & \\
\hline & 2 & $4(25 \%)$ & 0 & \\
\hline & 0 & $10(62,5 \%)$ & $16(100 \%)$ & \multirow[t]{3}{*}{0,008} \\
\hline & 1 & $5(31,25 \%)$ & 0 & \\
\hline & 2 & $1(6,25 \%)$ & 0 & \\
\hline
\end{tabular}

Keterangan: *Nilai p <0,05 : signifikan, diketahui berdasarkan uji Mann Whitney 
Pada tabel 3. Hasil uji diperoleh nilai $\mathrm{p}<0,05$ artinya ada perbedaan bermakna terhadap skor penyembuhan luka perineum pada kedua kelompok, dimana yang dirawat dengan $V C O$ lebih cepat sembuh dibandingkan dengan yang dirawat sesuai standar persalinan normal. Kalau dilihat dari rata-rata hari penyembuhan adalah pada kelompok control rata-rata sembuh antara lima hari sampai delapan hari, sedangkan pada kelompok perlakuan rata-rata penyembuhan adalah empat sampai lima hari.

\section{Pembahasan}

Berdasarkan hasil analisis data penyembuhan luka perineum yang dirawat sesuai standar APN ditambah $V C O$ lebih cepat sembuh disbandingkan dengan yang dirawat sesuai APN. Perawatan luka pereum sesuai APN dengan membersihkan luka dengan air dan sabun serta menjaga kebersihan, menurut pengalaman sembuh pada hari ke tujuh.

Dari hasil pengamatan 16 orang kelompok kontrol yang dirawat sesuai APN sembuh pada hari ke tujuh $10(62,5 \%)$ skor REEDA 0 (sembuh), $5(31,25 \%)$ nilai 2 dan
$1(6,25 \%)$ nilai 1 artinya belum sembuh pada hari ke tujuh. Hambatan penyembuhan luka perineum bisa disebabkan oleh kontaminasi kumankuman dari luar atau yang berasal dari saluran vagina itu sendiri dan dari anus pada saat buang air besar.

Sedangkan pada kelompok perlakuan yang penyembuhan luka perineum dirawat sesuai APN ditambah dengan $V C O, 11$ orang sembuh pada hari ke empat dan sisanya 5 orang sembuh pada hari ke lima. Penyembuhan luka perineum sesuai APN ditambah virgi coconut oil lebih cepat sembuh karena VCO memiliki khasiat anti bakteri, anti virus, anti jamur dan bila dioleskan di atas luka bisa melapisi luka dan melindungi dari kontaminasi kotoran seperti debu dan kotoran yang lain. Untuk mengantisipasi terjadinya hambatan penyembuhan luka perineum yang disebabkan oleh kontaminasi kuman-kuman dari luar atau yang berasal dari saluran vagina itu sendiri dan dari anus saat buang air besar, maka perawatan lika perineum sebaiknya dengan APN ditambahkan dengan $V C O$.

Khasiat VCO ini berdasarkan hasil penelitian yang dilakukan oleh 
Dr. Mary Enig (2013) hampir 50\% dari fatty acid dalam kelapa adalah lauric acid. Lauric acid adalah perubahan dari fatty acid, yang mana tubuh manusia atau hewan yang dapat meningkatkan fungsinya menjadi monolaurin. Monolaurin merupakan anti-viral, antibacterial, and antiprotozoal monoglyceride yang mana dalam tubuh manusia atau hewan berguna untuk menghancurkan lipid coated viruses seperti HIV, herpes, cytomegalo virus, influenza, various pathogenic bacteria. ${ }^{6}$

Manfaat dan khasiat produk VCO. Ketika dioleskan pada goresan dan luka, VCO dapat membentuk lapisan tipis yang melindungi luka dari debu luar, bakteri maupun virus sehingga mempercepat proses penyembuhan, dan belum pernah ditemukan adanya efek samping. ${ }^{10}$

Selain khasiat tersebut di atas juga dari hasil penelitian Dr Robert L. Wickresinghe, kepala Divisi Serologi, Medical Research Insitute dari Sri Lanka mengungkapkan bahwa peran lain, $V C O$ bersamaan dengan sel darah putih adalah meningkatkan kekebalan tubuh, membantu melindungi tubuh dari serbuan bakteri patogen dan membersihkan sel kanker.

Hasil penelitian ini juga didukung oleh hasil penelitian eksperimental sungguhan yang dilakukan oleh Jaya, Fidi Bhawana, (2015) mengenai Efek Virgin Coconut Oil dalam Mempercepat Penyembuhan Luka., pada 30 ekor mencit galur Swiss Webster jantan dengan luka insisi yang dibagi secara acak dalam 3 kelompok perlakuan $(n=10)$ yaitu kelompok VCO, kelompok kontrol positif Povidone Iodine 10\% dan kelompok kontrol negative $\mathrm{NaCl}$ $0,9 \%$. Hasil Penelitian didapatkan VCO mempercepat penyembuhan luka secara makro-skopis. ${ }^{3}$

Pada penelitian lain yang dilakukan oleh Irawan Derajat Dewandono (2014) yang bertujuan untuk mengetahui pengaruh massage dengan $V C O$ dalam penyembuhan luka dekubitus derajat II di Panti Wredha. Hasil penelitian terapi massage dengan metode effleurage memakai $V C O$ berpengaruh positif yaitu memberikan sensasi nyaman terhadap kedua pasien lansia dan memberikan perkembangan luka yang cukup signifikan, luka tampak kering, warna kecoklatan, eritema tampak 
samar dan jaringan luka menutup tanpa adanya tanda-tanda infeksi. ${ }^{4}$

\section{Simpulan dan Saran}

Rata-rata lama penyembuhan
luka perineum ibu nifas dengan perawatan sesuai APN 6-7 hari. Ratarata lama penyembuhan luka perineum ibu nifas dengan perawatan sesuai APN ditambah dengan VCO, 4 sampai 5 hari. Ada perbedaan lama penyembuhan luka perineum antara ibu nifas dengan perawatan sesuai APN dengan ditambahvirgin coconut oil. Jadi lebih cepat sembuh yang dirawat sesuai APN yang ditambah $V C O$ dari pada yang hanya dirawat sesuai APN.

Disarankan pada praktisi kesehatan yang memberikan layanan persalinan normal apabila pasiennya mengalami luka perineum, untuk mempercepat penyem-buhannya sebaiknya dengan $V C O$, hingga ibu lebih cepat bisa melaksanakan perannya dalam merawat dan menyusui bayinya dengan nyaman.

\section{Sumber Pustaka}

1. Ikatan Bidan Indonesia. 2006. Standar Asuhan kebidanan. Jakarta
2. Suherni, dkk.Perawatan masa nifas. : Fitramaya .Yogyakarta.

3. Fidi Bhawana.2008. Efek Virgin Coconut Oil dalam Mempercepat Penyembuhan

Luka.Semarang.2015 https/www. Respository.maranatha.edu/8991

4. Derajatt. 2014. Terapi massage dengan VCO efek dalam meminimalisir terjadinya infeksi dan dapat menurunkan derajat luka dekubitus.

https://prezi.com..studi-koperatifperawatan.Jakarta.

5. Robert. 2014. Harapan kesembuhan untuk pasien pada virgin coconut

oil.http://virgincoconutoil.asia/ha rapan-kesembuhan-untuk-pasienpada-virgin-coconut-oil

6. Diana Herrington. 2013. Amazing Health benefits On Virgin Coconut Oil/ Care Healthy.Jakarta.

http://www.care2.com/greenlivin g/the-amazing-health-benefits-ofvirgin-coconutoil.html\#ixzz3ZKZ3Nwuk

7. Sugiono.2008. Metodelogi Penelitian. Jakrta.

8. Boyle, M.2008. Pemulihan Luka. : EGC .Jakarta..

9. Mahishale et al.2013. Effect of therapiutic ultrasound and maternal cooling gel pad for perineal pain following vaginal delivery with episiotomy. $\mathrm{J}$ Women's Health Care. 2(3). ISSN: 2167-0420;

10. Careline.2014.Manfaat dan Khasiat Produk Virgin Cocconut Oil.Jakarta. http://virgincoconutoil.asia/manf aat-dan-khasiat-produk- vco 